\title{
Hodgkin's Lymphoma with Leptomeningeal Involvement
}

\author{
Leptomeningeal Tutulumlu Hodgkin Lenfoma
}

\author{
Rahşan Yıldırım ${ }^{1}$, Mehmet Gündoğdu ${ }^{1}$, Fuat Erdem ${ }^{1}$, İlhami Kiki ${ }^{1}$, Betül Gündoğdu ${ }^{2}$ \\ ${ }^{1}$ Atatürk University, School of Medicine, Department of Internal Medicine, Division of Hematology, Erzurum, Turkey \\ ${ }^{2}$ Atatürk University, School of Medicine, Department of Pathology, Erzurum, Turkey
}

\begin{abstract}
A 31-year-old male patient with Hodgkin's lymphoma (HL) and leptomeningeal involvement presented to at Hematology Departments of Atatürk University. The patient developed dizziness, limb weakness, involuntary contractions of the hands and feet, incontinence, headache, fever, nausea, and vomiting following the first cycle of treatment with the ABVD protocol (adriamycin $25 \mathrm{mg} \mathrm{m}^{-2}$, bleomycin $10 \mathrm{mg} \mathrm{m}^{-2}$, vinblastin $6 \mathrm{mg} \mathrm{m}^{-2}$, and dacarbazine $375 \mathrm{mg} \mathrm{m}^{-2}$ on d 1 and 15 of a 28-d cycle). Magnetic resonance imaging (MRI) showed that there were regions with infiltration in particularly the thoracic vertebrae (T3, T4, T9, and T10-T12). In the lumbar region leptomeningeal involvement beginning at the end of the medulla spinalis that gave rise to a separation of nerves in the cauda equine was observed. Contrast agent uptake was observed, especially at the dural sac, with edema in the nerve roots.
\end{abstract}

Key Words: Leptomeningeal involvement, Hodgkin's lymphoma

Özet

Otuz bir yaşında leptomeningeal tutulumu olan Hodgkin's Lenfoma (HL)'lı erkek hasta sunuldu. Hastada, ABVD (Adriamycin $25 \mathrm{mg} / \mathrm{m} 2$, bleomycin $10 \mathrm{mg} / \mathrm{m} 2$, vinblastine $6 \mathrm{mg} / \mathrm{m} 2$, dacarbazine $375 \mathrm{mg} / \mathrm{m} 2$ on days 1 and 15 of a 28-day cycle) tedavisinin ilk siklusundan sonra baş dönmesi, ekstremitelerde güçsüzlük, el ve ayaklarda istemsiz kasılma, inkontinans, baş ağrısı, ateş, bulantı ve kusma gelişti. Magnetic resonance imaging (MRI)'da özellikle torakal vertebralarda (T3, T4, T9, T10-T12), infiltrasyon ile uyumlu alanlar görüldü. Lomber bölgede medulla spinalisin son kısmından başlayan, kauda equinadaki sinirlerde ayrılmaya sebep olan leptomeningeal tutulum görüldü. Sinir köklerinde ödem ile birlikte özellikle dural kesede kontrast madde tutulumu görüldü.

Anahtar Sözcükler: Leptomeningeal tutulum, Hodgkin lenfoma

Address for Correspondence: Rahşan YILDIRIM, M.D.,

Atatürk Üniversitesi, Tıp Fakültesi, Yakutiye Araştırma Hastanesi İç Hastalıkları Anabilim Dalı, 25100 Erzurum, Turkey

Phone: +90 4422317195 E-mail: rahsan.yildiri@hotmail.com

Received/Geliş tarihi : February 9, 2010

Accepted/Kabul tarihi : May 25, 2010 


\section{Introduction}

Although primary and secondary involvement of the central nervous system (CNS) can be seen in patients followed-up for various hematological malignancies, they are not very common in patients with malignant lymphomas. CNS involvement leads to increases in morbidity and mortality [1]. The frequency of CNS involvement is $0.2 \%-0.5 \%$ in patients with advanced stage Hodgkin's lymphoma (HL) [2]. Leptomeningeal involvement in various malignancies is not common $[3,4]$ and in Hodgkin's disease it is rare [5]. As such, herein we present an HL patient with involvement of the leptomeninges.

\section{Case Report}

A 31-year-old, male presented with complaints of night sweats, fever, weight loss ( $8 \mathrm{~kg})$, and cervical and axillary lymphadenopathy, which began 2 months earlier at Hematology Departments of Atatürk University. Written informed consent to publish the details of his clinical course and treatment was obtained from the patient at the time of presentation. The patient's personal and family medical histories were non-specific. Physical examination showed that his vital functions were normal; body temperature was $38.7^{\circ} \mathrm{C}$, and blood pressure and pulse were 110/70 $\mathrm{mmHg}$ and $108 \mathrm{~min}^{-1}$, respectively. The patient had generalized, mobile elastic lymphadenopathies (maximum diameter of $4 \mathrm{~cm}$ ) in the cervical, axillary, and inguinal regions. The liver and spleen were palpable 3 and $5 \mathrm{~cm}$ below the costal margin, respectively.

Admission of hospital, the patient had the following findings: white blood cell count: $3 \times 10^{9} \mathrm{~L}^{-1}$; hemoglobin: $11 \mathrm{~g} \mathrm{dL}^{-1}$; platelet count: $158 \times 10^{9} \mathrm{~L}^{-1}$. The erythrocyte sedimentation rate was $55 \mathrm{~mm} \mathrm{~h}^{-1}$. Serum biochemistry findings were within normal limits, except for serum lactate dehydrogenase, which was $560 \mathrm{IU} \mathrm{L}^{-1}$ (normal range: 150-450 IU L-1). C-reactive protein was $18 \mathrm{mg} \mathrm{L}^{-1}$ (normal range: $0-0.5 \mathrm{mg} \mathrm{L}^{-1}$ ). In posterior-anterior radiography hilar enlargement was the only pathology observed.. on 30 March 2009, nodular sclerosing HL was diagnosed via histopathological evaluation of a cervical lymph node biopsy specimen, and treatment with the ABVD protocol (adriamycin $25 \mathrm{mg} \mathrm{m}^{-2}$, bleomycin $10 \mathrm{mg} \mathrm{m}^{-2}$, vinblastin $6 \mathrm{mg} \mathrm{m}^{-2}$, and dacarbazine $375 \mathrm{mg} \mathrm{m}^{-2}$ on $\mathrm{d} 1$ and 15 of a 28-d cycle) started on 1 April 2009.

The patient's diameter of lymph nodes regressed to $1.5-2 \mathrm{~cm}$, and night sweats and fever became less severe $15 \mathrm{~d}$ after starting the ABVD chemotherapy protocol. The patient presented on 1 May 2009 for the second cycle of chemotherapy and reported having experienced dizziness, limb weakness, involuntary contractions of the hands and feet, which lasted a few minutes, and occurred 1-2 times $\mathrm{d}^{-1}$ and gradually increased in frequency, and incontinence, headache, fever, nausea, and vomiting began the previous week. Physical examination showed bilateral cervical and axillary lymphadenopathies with a maximum diameter 2 $\mathrm{cm}$. Neurological examination showed bilateral weakness (3/6) in the lower extremities associated with loss of deep tendon reflexes, hypoesthesia in the lower extremities (mostly in distal regions), proprioceptive sensory disturbance, and epileptic convulsions. Blood count and serum biochemistry findings were unremarkable. Fundus examination showed that the optic disc margins in both eyes were blurred. Craniospinal involvement was considered based on clinical symptoms and lumbar puncture, and cerebrospinal fluid cytology and cytocentrifugation were planned; however, due to abnormal fundoscopic findings they could not be performed at that time.

Cranial brain magnetic resonance imaging (MRI) showed that the patient had hydrocephalus. Vertebral MRI showed changes in intensity indicative of infiltration; thoracic vertebral corpuses appeared hypointense in $\mathrm{Tl}$-weighted images and hyperintense in $\mathrm{T} 2$ weighted images (Figure 1), particularly vertebrae T3, T4, T9, and T10-12. Similar findings were noted in vertebrae L1-L2-L3 and the sacrum. Additionally, the appearance of the lumbar region starting from the end of the medulla spinalis that caused edema in nerve roots and contrast agent uptake-particularly in the dural sac — giving rise to a separation of nerves in cauda equina were interpreted as leptomeningeal involvement (Figure 2). Electro encephalo myelography findings were normal.

As the patient was considered to have leptomeningeal involvement, on 10 May 2009 radiotherapy was commenced; 3600 cGy was administered primarily to the regions of vertebral involvement, and then to the entire cranium for 20 days. Following radiotherapy, the frequency of epileptic convulsions decreased gradually and eventually ceased. As post-radiotherapy fundoscopic findings were normal, cerebrospinal fluid testing could be performed. Glucose was $22 \mathrm{mg} \mathrm{dL}^{-1}$ (normal range: 40-70 $\mathrm{mg} \mathrm{L}^{-1}$ ) and microprotein was $58 \mathrm{mg} \mathrm{dL}^{-1}$ (normal range: $15-45 \mathrm{mg} \mathrm{L}^{-1}$ ). No tumor cells were observed via cytocentrifugation or cytology. Event hough the patient's epileptic convulsions gradually decreased in frequency and ceased following radiotherapy, other neurological symptoms persisted and were progressive; therefore the patient underwent physiotherapy for paraplegia. The patient was treated with 1 cycle of ifosfamide, carboplatin, and etopo- 


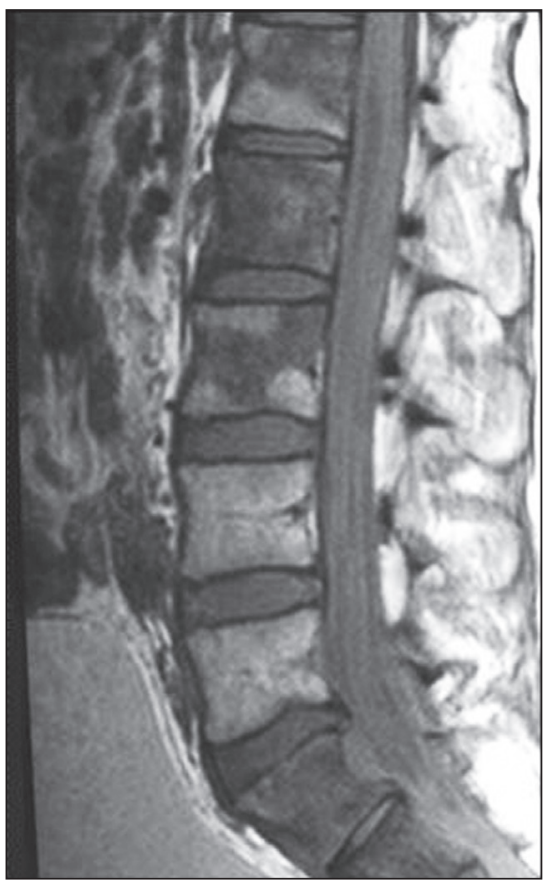

Figure 1: Bone

lesions in lumbosacral vertebrae.

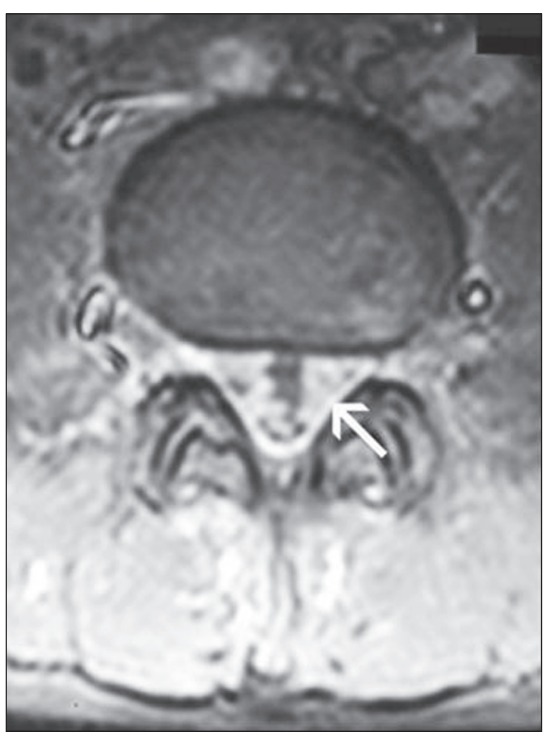

Figure 2:

Leptomeningeal involvement (white arrow).

side (ICE) on 20 June 2009; however, the patient's clinical condition deteriorated gradually and he died due to respiratory failure on 15 . day of the chemotherapy cycle.

\section{Discussion}

Neurological complications of HL have been reported frequently and are generally observed after the disease is diagnosed [6]. In the presented case neurological involvement was detected 1 month after the diagnosis of HL. Although neurological involvement in HL manifests as spinal cord lesions rather than intracranial lesions, intracranial involvement usually appears via tumoral invasion via cranial and meningeal involvement [6-8], or via the hematogenous route [9-11]. Neurological hydrocephaly occurred together with leptomeningeal involvement in the presented case. Intramedullary cord metastasis does not occur frequently in HL and when it does it indicates a poor prognosis [12].

The frequency of CNS involvement is $0.2 \%-0.5 \%$ in advanced stage HL patients [2]. CNS involvement in HL can be seen in patients that relapse frequently (as in the presented case) and in immunodeficient patients at the time of diagnosis [13]. CNS involvement leads to increases in morbidity and mortality [1]. Leptomeningeal involvement, as observed in the presented case, occurs more frequently in patients with such malignancies as non-Hodgkin's lymphoma and carcinomas than in those with HL, and is diagnosed based on evaluation of clinical presentation and detection of malignant cells during cytological analysis of cerebrospinal fluid. It could be necessary to repeat the analysis because of the diagnostic yield of the cytologic analysis of cerebrospinal fluid $[13,14]$.

Although the clinical findings in the presented case strongly suggested neurological involvement, cerebrospinal fluid analysis and intrathecal therapy could not be performed due to abnormal fundoscopic findings; however, leptomeningeal involvement was confirmed via cranial or vertebral MRI findings. Following radiotherapy, cytological analysis and cytocentrifugation of the patient's cerebrospinal fluid showed that there were no cells, whereas biochemical analysis showed an increase in microprotein levels and a decrease in the glucose level, suggesting leptomeningeal involvement. According to previous reports, remission can be achieved with intrathecal chemotherapy and cranial radiotherapy in patients with leptomeningeal involvement [15], although it was not achieved in the presented patient.

Figueroa et al. reported a 23-year-old female patient with cerebral mass imaging findings consistent with meningioma and nodular sclerosis-type HL that underwent excisional biopsy. As in the presented case, corpus vertebrae involvement was noted, and subsequent analysis of her cerebrospinal spinal showed no sign of involvement. She achieved complete remission following systemic chemotherapy, radiotherapy, and intrathecal treatment [16]. Akyüz et al. reported 3 patients with intracranial involvement that had intracranial recurrence about 36 months after initial diagnosis despite receiving systemic chemotherapy and low-dose radiotherapy to the involved area. In this case, intracranial involvement was detected using computerized tomography and MRI in these 3 patients, 
and cerebrospinal fluid was analyzed cytologically. Again, as in the presented case, these 3 patients died despite systemic chemotherapy and external radiotherapy to the cranial lesions. While involvement was only in the form of metastatic lesions in these 3 patients, leptomeningeal and metastatic lesions coexisted in the presented case. In addition, CNS involvement was noted 1 month after the diagnosis, in other words, only at the start of the second cycle of treatment [17]. Morawa et al. reported a male patient with Down syndrome and mixed cellular-type HL that had tonic clonic seizures; CNS involvement was noted after 5 cycles of treatment, even though complete remission was achieved following 4 cycles of the ABVD protocol. In the presented case CNS involvement was noted after 1 cycle of the ABVD chemotherapy protocol and clinical presentation were similar to that in the their patient. The researchers reported that the patient's mass in the right ventricle observed with the MRI was consistent with the HL and that radiotherapy resulted in remission [18]. Leptomeningeal involvement was not present in any of the last four cases described. The presented case is different from these four cases in this regard.

The presented case had nodular sclerosing HL with a rapidly progressive course due to leptomeningeal involvement during chemotherapy. Although it is difficult to diagnose such neurological complications as leptomeningeal involvement or cranial nerve paralysis, it is important that they be diagnosed and treated early in order to improve patient quality of life and lower the mortality rate. CNS and leptomeningeal involvement occurred in the presented nodular sclerosing HL patient. While nodular sclerosing HL has relatively better prognosis than those of other types of HL, the progression of the case while getting chemotherapy lead us to report this case.

\section{Conflict of interest statement}

The authors of this paper have no conflicts of interest, including specific financial interests, relationships, and/ or affiliations relevant to the subject matter or materials included.

\section{References}

1. Lister A, Abrey LE, Sandlund JT. Central nervous system lymphoma. Hematology Am Soc Hematol Educ Program 2002; 1: 283-296

2. Blake PR, Carr DH, Goolden AW. Intracranial Hodgkin's disease. Br J Radiol 1986; 59: 414-416
3. Olson ME, Chernik NL, Posner JB. Infiltration of the leptomeninges by systemic cancer. Arch Neurol 1974; 30: 122-137

4. Shapiro WR, Posner JB, Ushio Y, Chernik NL, Young DF. Treatment of meningeal neoplasms. Cancer Treat Rep 1977; 61: 733-743

5. Ultmann JE, Moran EM. Hodgkin's disease: Clinical course and complications. Arch Intern Med 1973; 131: 322-353

6. Eyre DP. Neurological complications of Hodgkin's disease. Postgrad Med J 1966; 42: 723-724

7. Marshall G, Roesmann U, Van den Noort S. Invasive Hodgkin's disease of the brain: Report of two new cases and review of the American and Eurepean literature with clinical pathological correlations. Cancer 1968; 22 (3): 621-630

8. Kaufman G. Hodgkin's disease involving the central nervous system. Arch Neurol 1965; 13: 555-558

9. Sapozink MD, Kaplan HS. Intracranial Hodgkin's disease: A report of 12 cases and review of the literature. Cancer 1983; 52: 1301-1307

10. Scheithauer BW. Cerebral metastases in Hodgkin's disease. Arch Pathol Lab Med 1979; 103: 284-287

11. Ashby MA, Barber PC, Holmes AE, Freer CE, Collins RD. Primary intracranial Hodgkin's disease. A case report and discussion. Am J Surg Pathol 1988; 12: 294-299

12. Guermazi A, Brice P, de Kerviler E E, Fermé C, Hennequin C, Meignin V, Frija J. Extranodal Hodgkin's disease: spectrum of disease. Radiographics 2001; 21: 161-179

13. Anselmo AP, Proia A, Cartoni C, Baroni CD, Maurizi Enrici R, Delfini R, Avvisati G. Meningeal localization in a patient with Hodgkin's disease: Description of a case and review of the literature. Ann Oncol 1996; 7: 1071-1075

14. Young RC, Howser DM, Anderson T, Fisher RI, Joffe E, De Vita VT Jr. Central nervous system complications of nonHodgkin's lymphoma. Am J Med 1979; 66: 435-443

15. Orlowski EP, Hansen RM, Anderson T, Hanson GA, Kun LE, Pisciotta AV. Hodgkin's disease with leptomeningeal involvement. Report of a case with long survival. Cancer 1984; 53: 1833-1835

16. Figueroa BE, Brown JR, Nascimento A, Fisher DC, Tuli S. Unusual Sites of Hodgkin's Lymphoma CASE 2. Hodgkin's Lymphoma of the CNS Masquerading As Meningioma. J Clin Oncol 2004; 22: 4228-4230

17. Akyüz C, Yalcin B, Atahan IL, Varan A, Kutluk MT, Büyükpamukçu M. Intracranial involvement in Hodgkin's disease. Pediatr Hematol Oncol 2005; 22: 589-596

18. Morawa E, Ragam A, Sirota R, Nabhan C. Hodgkin's lymphoma involving the CNS. J Clin Oncol 2007; 25: 14371438 